\title{
Antioxidant Activities and Nutritional Components of Cricket (Gryllus bimaculatus) Powder and Protein Extract
}

\author{
Si-Hyun Kim ${ }^{1}$, Yookyung Kim², Jung-Soon $\mathrm{Han}^{3 *}$ \\ ${ }^{1}$ Department of Human Ecology, Korea University, Seoul, Korea \\ ${ }^{2}$ Department of Home Economics Education, College of Education, Korea University, Seoul, Korea \\ ${ }^{3}$ Research Institute of Human Ecology, Korea University, Seoul, Korea
}

\author{
"Corresponding author: Jung-Soon Han, \\ Research Institute of Human Ecology, \\ Korea University, 145 Anam-ro, Seongbuk- \\ gu, Seoul 02841, Korea \\ Tel.: +82 232901672 \\ Email: yohwa0960@korea.ac.kr
}

Received April 02, 2020

Revised April 15, 2020

Accepted April 23, 2020

Published June 30, 2020

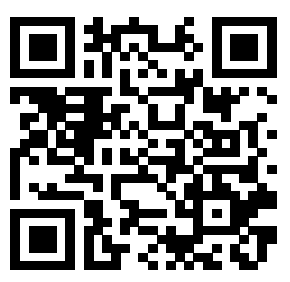

\begin{abstract}
Purpose: In the present study, we evaluated the amino acids, antioxidant activities of cricket (Gryllus bimaculatus) powder and protein extract. Methods: Moisture, crude fat, protein, and mineral content were measured via chemical analysis according to Association of Official Analytical Chemists (AOAC) guidelines. Amino acid composition was analyzed using an automatic amino acid analyzer. The antioxidant activities of cricket (G. bimaculatus) powder extract (CPE) and cricket (G. bimaculatus) powder protein extract (CPPE) calculated by assessing the total polyphenol content and the radical scavenging activities of the radicals 1,1-diphenyl-2-picrylhydrazyl (DPPH). Results: CPE had higher values of $\mathrm{Ca}$ and $\mathrm{K}$, than CPPE. CPE had higher essential amino acid amounts compared to CPPE. CPE's branched chain amino acid contents [i.e., valine (CPE, $17186.31 \mathrm{mg} / \mathrm{kg}$; CPPE, $1147.28 \mathrm{mg} / \mathrm{kg})$, leucine (CPE, $25382.52 \mathrm{mg} / \mathrm{kg}$; CPPE, $2753.34 \mathrm{mg} / \mathrm{kg}$ ), and isoleucine (CPE, $12790.01 \mathrm{mg} / \mathrm{kg}$; CPPE, $1281.90 \mathrm{mg} / \mathrm{kg})$ ] significantly higher values than CPPE. The total polyphenol content of CPPE (12.18 mg GAE/g) was higher than CPE (6.61 mg GAE/g). DPPH radical scavenging activity of CPPE (80.37\%) was also higher than CPE (68.25\%). Conclusion: Therefore, the results of this study suggest that cricket (G. bimaculatus) is a suitable protein and natural antioxidant material for health improvement. In the future, further studies on the health benefits of cricket ( $G$. bimaculatus) should be conducted.
\end{abstract}

Keywords: Cricket (Gryllus bimaculatus) powder, Protein extract, Amino acids, Mineral, Antioxidant activity

\section{Introduction}

세계인구는 영양상태 개선과 과학과 의료기술의 발달로 인해 수 명이 연장되어 폭발적으로 증가하고 있는데 비해 기후와 환경 변 화 등에 의해 식량수급은 제대로 이루어지고 있지 않으며 특히 단 백질 식품의 부족이나 수급문제는 심각한 쟁점으로 대두되고 있다 (Alston et al., 2009). 이러한 식량부족과 단백질 식품 수급 문제를 해결할 수 있는 방안 중 하나로 세계 여러 지역에서 오래 전부터 전 통적으로 식용해온 식용곤충이 대안으로 제시되고 있으며 이에 대 한 관심이 증대하고 있다(Hegsted et al., 1993). 식용곤충은 동물 성 단백질의 주요 공급원인 가축에 비해 짧은 생애주기를 가지고 있 어 공급이 용이한 식량 자원이며(Chung et al., 2013), 적은 양의 물
과 사료, 공간으로 경제적 비용 절감 효과와 농약이나 항생제를 사 용하지 않고 온실가스를 적게 방출해 자연 그대로의 환경을 유지할 수 있어 생태계를 보존하고 환경 오염을 줄일 수 있다는 장점이 있 다(Arsenault \& Brown, 2017). 영양적인 면에서도 식용곤충은 단 백질과 지방함량이 높은 매우 우수한 양질의 단백질 공급원으로 알 려지고 있다(Chung et al., 2013; Kim et al., 2015). 우리나라에서 도 2010 년 농림축산식품부가 곤충산업 성장의 필요성을 인지하여 ' 곤충 산업의 육성 및 지원에 관한 법률'을 제정하고, '제1차 곤충 산 업 육성 5 개년 종합 계획'을 실시하면서 곤충 산업이 급속도로 성장 하고 있다. 2016년에는 '제2차 곤충산업 육성 5 개년 계획'이 시작되 어 식용곤충시장 규모가 폭발적으로 급증하고 있다(Hwang \& Choi, 2015; Jung et al., 2018; Kim et al., 2014). 이렇듯 식용곤충에 
대한 관심이 증가하여 학습, 애완, 약리작용 등의 용도로 활용되고는 있으나(Lee \& Kang, 2019) 식품으로서의 활용에 대해서는 밀웜에 대 한 연구(Kang et al., 2017; Lee et al., 2019; Min et al., 2016)가 대 부분이며 다른 식용곤충에 대해서는 연구가 활발하게 이루어지고 있 지 않다. 쌍별귀뚜라미에 관한 연구로는 쌍별귀뚜라미 식품 용도 개 발에 따른 절식조건(Ahn et al., 2015), 인슐린 결핍 당뇨 마우스에서 식용곤충 쌍별귀뚜라미 추출물의 항당뇨 활성(Cho et al., 2019) 등이 있지만 아직까지 많지 않은 실정이다. 이에 본 연구는 식용곤충 중 쌍 별귀뚜라미 분말과 분말 단백질 추출물의 일반성분과 무기질성분, 필 수 아미노산, 비필수 아미노산 조성과 함량, 항산화능을 탐색하여 향 후 쌍별귀뚜라미를 이용한 식품소재나 최근 노인들의 건강을 위협하 고 있는 근감소 예방관련 식품이나 화장품 및 의약품 개발에 도움이 되는 자료로 활용하고자 수행되었다.

\section{Methods}

\section{1. 시료제조}

본 실험에 사용한 쌍별귀뚜라미는 2019년 10월 귀뚜라미 농원 (Chungbuk, Korea)에서 구입하여 2일간 절식시켜 세척한 다음 쪄서 건조 $\left(60^{\circ} \mathrm{C}\right)$ 한 후 믹서기(DA 5000; Daesungartlon, Korea)로 분쇄 후 분말로 하였으며 쌍별귀뚜라미 분말 단백질 추출물은 에탄올로 탈 지하고 단백질을 추출한 후 분말과 함께 동결 건조하여 시료로 사용 하였다.

\section{2. 일반성분 분석}

쌍별귀뚜라미 분말의 일반성분은 공인분석화학자협회(Association of Official Analytical Chemists, AOAC) 방법(AOAC, 2000)에 따라 수분은 $105^{\circ} \mathrm{C}$ 상압가열건조법, 조단백질은 semimicro kjeldahl법, 조 회분은 $550^{\circ} \mathrm{C}$ 직접회화법으로 분석하였다. 탄수화물 함량은 분석된 수분, 조단백질, 조지방, 조회분 함량으로부터 계산하였다.

\section{3. 무기질 함량 분석}

쌍별귀뚜라미 분말 시료 $0.1 \mathrm{~g}$ 에 질산 $9 \mathrm{~mL}$ 을 넣고 watch glass로 덮어 $200^{\circ} \mathrm{C}$ 에서 가열한 후 산에 의해 분해된 시료를 깨끗이 씻은 후 과염소산 용액 $3 \mathrm{~mL}$ 을 넣고 다시 $250^{\circ} \mathrm{C}$ 에서 가열한 다음 washing 한 후 $1 \%$ 질산으로 $15 \mathrm{~g}$ 으로 맞춘 후 시료로 사용하였다. 무기질 분 석은 ICP-OES Ultima Expert (HORIBA Jobin Yvon, France)를 사 용하여 분석하였다.

\section{4. 아미노산 조성 분석}

아미노산 분석을 위하여 쌍별귀뚜라미 분말과 분말 단백질 추 출물에 $6 \mathrm{~N}$ 염산용액 $30 \mathrm{~mL}$ 을 둥근 플라스크에 넣고 혼합한 다음 $130^{\circ} \mathrm{C}$ 에서 $24 \mathrm{~h}$ 동안 가수분해한 후 초순수로 희석시키고 여과지 (0.45 $\mu \mathrm{m}$; Whatman, UK)로 여과하였다. 가수분해 한 시료를 중 화하여 3차 증류수로 희석한 후 고성능 액체 크로마토그래피(high performance liquid chromatography, HPLC, Dionex UltiMate 3000; Thermo Scientific, USA)를 이용하여 분석하였다.

\section{Total polyphenol 함량}

쌍별귀뚜라미 분말과 분말 단백질 추출물의 총 폴리페놀 함량은 Folin-Denis의 방법(Folin \& Denis, 1912)을 변형한 방법에 따라 측정하였다. $90 \%$ diethylene glycol $10 \mathrm{~mL}$ 에 시료 $0.2 \mathrm{~mL}$ 을 가하 여 혼합하고 $4 \mathrm{~N} \mathrm{NaOH}$ 용액 $0.2 \mathrm{~mL}$ 을 가하여 $30^{\circ} \mathrm{C}$ 에서 정치한 후 분광광도계(Ultraspec 2100 pro; Biochrom, USA)를 이용하여 420 $\mathrm{nm}$ 에서 흡광도를 측정하였다. 갈산(gallic acid)을 표준물질로 사용 하였으며 결과는 $\mathrm{mg}$ 갈산 당량 $(\mathrm{GAE}) / \mathrm{g}$ 으로 표시하였다.

\section{DPPH radical 소거능}

쌍별귀뚜라미 분말과 분말 단백질 추출물의 DPPH (SigmaAldrich, USA) 라디칼 소거능은 Blois의 방법(Blois, 1958)을 변형 하여 다음과 같이 실시하였다. 시료 $5 \mathrm{~mL}$ 에 $\mathrm{DPPH}$ 용액을 가하여 실온 암소에서 $30 \mathrm{~min}$ 정치한 후 분광광도계(Ultraspec 2100 pro) 를 이용하여 $517 \mathrm{~nm}$ 에서 흡광도를 측정하였다.

\section{7. 자료분석}

모든 자료는 3 회 반복하여 평균과 표준편차 $(m e a n \pm \mathrm{SD})$ 로 표시 하였다.

\section{Results and Discussion}

\section{1. 일반성분}

쌍별귀뚜라미 분말의 일반성분은 Table 1 에 제시하였다. 쌍별귀 뚜라미 분말의 수분 $3.86 \%$, 회분 $4.41 \%$, 조단백질 $61.05 \%$, 조지방 $19.08 \%$, 탄수화물 $11.60 \%$ 로 다른 식용곤충에 비해 단백질 함량이 월등히 높았고 지방은 적었다. 본 실험에서 쌍별귀뚜라미 분말의 수 분함량은 $3.86 \%$ 로 갈색거저리유충 $2.90 \%$ 보다는 다소 높고, 흰점박 이꽃무지유충 $6.66 \%$ 보다는 낮고 장수풍뎅이 유충 $1.63 \%$ 보다는 높

Table 1. The general composition of cricket (Gryllus bimaculatus) powder extract

\begin{tabular}{lccccc}
\hline Samples & Moisture & Crude ash & Crude protein & Crude fat & Carbohydrate \\
Cricket $(\%)$ & $3.86 \pm 0.23^{1)}$ & $4.41 \pm 0.60$ & $61.05 \pm 1.06$ & $19.08 \pm 0.16$ & $11.60 \pm 0.74$ \\
\hline
\end{tabular}

${ }^{1)}$ Mean \pm standard deviation. 
았다(Baek et al., 2017). 탄수화물 함량은 $11.60 \%$ 로 갈색거저리유 충 $9.32 \%$ 보다는 높았고, 흰점박이꽃무지유충 $10.56 \%$ 과는 비슷하 였으며 장수풍뎅이유충 28.61\%보다는 낮았다(Baek et al., 2017). 조단백질 함량은 $61.05 \%$ 로, 갈색거저리유충 $50.32 \%$, 흰점박이꽃 무지유충 $57.86 \%$, 장수풍뎅이유충 $39.31 \%$ 보다 높아 식용곤충 중 가장 높았다(Baek et al., 2017). 조지방 함량은 $19.08 \%$ 로 갈색거저 리 유충 $33.7 \%$, 장수풍뎅이유충 $25.21 \%$ 보다는 낮았으나, 흰점박이 꽃무지유충 $16.57 \%$ 보다는 높았다(Baek et al., 2017). 지방함량보 다 단백질 함량이 많은 것은 근육관련 질환이나 노인의 근감소 예방 및 중장년 이후 혈중 지질이 높아지는 것을 예방하기 위한 식품소재 나 식품으로서도 긍정적일 것으로 사료되며, 특히 지방과 탄수화물 함량이 적어 다이어트 소재로서의 활용이 기대되는 뷰티푸드 소재 로도 활용될 수 있을 것으로 사료된다.

\section{2. 쌍별귀뚜라미 분말과 분말 단백질 추출물의 무기질 성분}

쌍별귀뚜라미 분말과 분말 단백질 추출물의 무기질 성분은 Table 2 에 제시한 바와 같다. 쌍별귀뚜라미 분말 추출물의 무기질 성분 은 칼슘 $110.8 \mathrm{mg} / 100 \mathrm{~g}$, 칼륨 $724.7 \mathrm{mg} / 100 \mathrm{~g}$, 나트륨 289.3 $\mathrm{mg} / 100 \mathrm{~g}$, 인 $74.0 \mathrm{mg} / 100 \mathrm{~g}$, 아연 $22.1 \mathrm{mg} / 100 \mathrm{~g}$ 이었으며, 쌍 별귀뚜라미 분말 단백질 추출물에는 칼슘 $2.5 \mathrm{mg} / 100 \mathrm{~g}$, 칼륨 8.6 $\mathrm{mg} / 100 \mathrm{~g}$, 나트륨 $91.0 \mathrm{mg} / 100 \mathrm{~g}$, 인 $98.0 \mathrm{mg} / 100 \mathrm{~g}$, 아연 23.5 $\mathrm{mg} / 100 \mathrm{~g}$ 이 함유되어 있었다. 본 연구에서 쌍별귀뚜라미 분말의 칼슘함량은 $110.8 \mathrm{mg} / 100 \mathrm{~g}$ 으로 갈색거저리유충 $34.9 \mathrm{mg} / 100 \mathrm{~g}$ 에 비해 약 3 배 가량 높았고, 장수풍뎅이 유충 $302.4 \mathrm{mg} / 100 \mathrm{~g}$ 보다
는 낮게 나타났다. 그러나 현재 많이 식용되고 있는 돼지고기(3.39$6.12 \mathrm{mg} / 100 \mathrm{~g}$ )에 비해서는 월등하게 높았다(Baek et al., 2017). 칼륨 함량은 $724.7 \mathrm{mg} / 100 \mathrm{~g}$ 으로 흰점박이꽃무지 유충 1597 $\mathrm{mg} / 100 \mathrm{~g}$, 갈색거저리 유충 $865.15 \mathrm{~g} / 100 \mathrm{~g}$ 보다 낮게 나타났다. 이상의 결과를 보면 쌍별귀뚜라미 분말에는 칼슘 함량이 많아 노인 들의 골다공증예방과 개선(Han \& Kim, 2019)이나 성장기 아동, 청 소년기 건강증진에도 긍정적일 것으로 사료된다. 또한 칼륨은 혈압 을 낮추는 생리활성 기능이 있어(Ophir et al., 1983; Singer et al., 1990) 쌍별귀뚜라미는 고혈압을 예방할 수 있는 기능성 소재로서의 활용도 기대할 수 있을 것으로 판단된다.

3.쌍별귀뚜라미 분말과 분말 단백질 추출물의 필수 아미노산 성분 쌍별귀뚜라미 분말과 분말 단백질 추출물의 필수 아미노산 성분 은 Table 3 에 제시한 바와 같다. 쌍별귀뚜라미 분말 추출물에는 필 수 아미노산 중 히스티딘 $10380.00 \mathrm{mg} / \mathrm{kg}$, 트레오닌 12679.04 $\mathrm{mg} / \mathrm{kg}$, 아르기닌 $32189.42 \mathrm{mg} / \mathrm{kg}$, 발린 $17186.31 \mathrm{mg} / \mathrm{kg}$, 메 티오닌 $6077.52 \mathrm{mg} / \mathrm{kg}$, 트립토판 $340.03 \mathrm{mg} / \mathrm{kg}$, 페닐알라닌 $12249.08 \mathrm{mg} / \mathrm{kg}$, 이소루이신 $12790.01 \mathrm{mg} / \mathrm{kg}$, 루이신 25382.52 $\mathrm{mg} / \mathrm{kg}$, 리신 $12050.90 \mathrm{mg} / \mathrm{kg}$ 이 함유되어 있었으며, 분말 단백질 추출물에는 히스티딘 $2763.08 \mathrm{mg} / \mathrm{kg}$, 트레오닌 $710.63 \mathrm{mg} / \mathrm{kg}$, 아르기닌 $2822.72 \mathrm{mg} / \mathrm{kg}$, 발린 $1147.28 \mathrm{mg} / \mathrm{kg}$, 메티오닌 679.55 $\mathrm{mg} / \mathrm{kg}$, 페닐알라닌 $1367.50 \mathrm{mg} / \mathrm{kg}$, 이소루이신 $1281.90 \mathrm{mg} /$ $\mathrm{kg}$, 루이신 $2753.34 \mathrm{mg} / \mathrm{kg}$, 리신 $900.17 \mathrm{mg} / \mathrm{kg}$ 이 함유되어 있었 다. 필수 아미노산은 체내에서 합성되지 않아 반드시 식사로 섭취해

Table 2. Mineral contents of cricket (Gryllus bimaculatus) powder and protein extract

(Unit: $\mathrm{mg} / 100 \mathrm{~g}$ )

\begin{tabular}{lrrrrr}
\hline Samples & $\mathrm{Ca}$ & $\mathrm{K}$ & $\mathrm{Na}$ & $\mathrm{P}$ & $\mathrm{Zn}$ \\
$\mathrm{CPE}$ & 110.8 & 724.7 & 289.3 & 74.0 & 22.1 \\
$\mathrm{CPPE}$ & 2.5 & 8.6 & 91.0 & 98.0 & 23.5 \\
\hline
\end{tabular}

CPE, cricket (Gryllus bimaculatus) powder extract; CPPE, cricket (Gryllus bimaculatus) protein powder extract.

Table 3. The essential amino acid (EAA) content of cricket (Gryllus bimaculatus) powder and protein extract

\begin{tabular}{lcc}
\hline & & Samples $(\mathrm{mg} / \mathrm{kg})$ \\
\cline { 2 - 3 } Amino acid & CPE & CPPE \\
Histidine & 10380.00 & 2763.08 \\
Threonine & 12679.04 & 710.63 \\
Arginine & 32189.42 & 2822.72 \\
Valine & 17186.31 & 1147.28 \\
Methionine & 6077.52 & 679.55 \\
Tryptophan & 340.03 & NA \\
Phenylalanine & 12249.08 & 1367.50 \\
Isoleucine & 12790.01 & 1281.90 \\
Leucine & 25382.52 & 2753.34 \\
Lysine & 12050.90 & 900.17 \\
\hline
\end{tabular}

CPE, cricket (Gryllus bimaculatus) powder extract; CPPE, cricket (Gryllus bimaculatus) protein powder extract. 
야 하는 아미노산으로 쌍별귀뚜라미 분말 추출물에는 10 가지 필수 아미노산이 골고루 다량 함유되어 있었다. 쌍별귀뚜라미 분말과 분 말 단백질 추출물 모두 분지아미노산(branched chain amino acid, $\mathrm{BCAA})$ 인 루이신, 이소루이신, 발린도 함유하고 있었는데 이러한 분 지아미노산은 골격근에서 산화되어 근육의 에너지원으로 이용되며 (Min et al., 2016), 근세포에서 단백질의 이화 작용을 억제시켜 근 세포의 단백질의 감소를 최소화 할 수 있고(Arsenault \& Brown, 2017), 장기간 운동을 할 때에는 근육의 에너지원으로 사용된다고 알려져 있으므로(Min et al., 2016), 분지아미노산이 많이 함유된 쌍별귀뚜라미는 근력증강(Na et al., 2016; No, 2010), 근육생성 과정(Chong et al., 2017)에 관여해 노인과 환자들의 근감소 예방 에 도움이 되는 식품, 성장기 아동이나 청소년들 뿐 아니라 일반인 들에게도 영양보충식 소재나 건강기능식품으로서의 활용가치가 있 을 것으로 기대된다. 또한 과잉의 육류섭취로 인해 혈중 지질의 증 가가 우려되는 사람들과 건강을 중요시 하는 현대인들의 요구에 부 합되는 적합한 식량대체자원으로 식품소재나 각종 기능성 식품으로 (Hwang \& Choi, 2015; Kim et al., 2014), 운동선수를 위한 단백 질 보충식품(Min et al., 2016), 환자를 위한 영양 보충식(Kang et al., 2017; Kim et al., 2015), 의약품과 기능성 화장품의 신소재 원 료로도 개발될 가능성이 있을 것으로 사료된다. 리신도 많이 함유 되어 있는데 리신은 콜라겐 합성에 관여하여 피부건강을 유지하고 피부노화를 억제하는데 도움을 주는 것으로 알려져 있어(Zhang et al., 2007) 향후 피부미용관련 소재나 뷰티푸드로서 이용될 수 있을 것이다.

\section{4. 쌍별귀뚜라미 분말과 분말 단백질 추출물의 비필수 아미노산} 조성 분석

쌍별귀뚜라미 분말과 분말 단백질 추출물의 비필수 아미노산 성 분은 Table 4 에 제시하였다. 쌍별귀뚜라미 분말 추출물에는 비필수 아미노산인 아스파르트산 $19451.30 \mathrm{mg} / \mathrm{kg}$, 글루탐산 36085.54 $\mathrm{mg} / \mathrm{kg}$, 세린 $18447.13 \mathrm{mg} / \mathrm{kg}$, 글루타민 $639.89 \mathrm{mg} / \mathrm{kg}$, 글리신 $21944.58 \mathrm{mg} / \mathrm{kg}$, 알라닌 $31947.01 \mathrm{mg} / \mathrm{kg}$, 타우린 $3309.13 \mathrm{mg} /$ $\mathrm{kg}$, 티로신 $17053.70 \mathrm{mg} / \mathrm{kg}$, 프롤린 $2834.81 \mathrm{mg} / \mathrm{kg}$, 쌍별귀뚜라 미 분말 단백질 추출물에는 아스파르트산 $1571.11 \mathrm{mg} / \mathrm{kg}$, 글루탐 산 $3266.08 \mathrm{mg} / \mathrm{kg}$, 세린 $730.02 \mathrm{mg} / \mathrm{kg}$, 글리신 $2617.74 \mathrm{mg} / \mathrm{kg}$, 알라닌 $1965.78 \mathrm{mg} / \mathrm{kg}$, 타우린 $83.44 \mathrm{mg} / \mathrm{kg}$, 티로신 1351.96 $\mathrm{mg} / \mathrm{kg}$ 이 함유되어 있었다. 비필수 아미노산 중 프롤린은 리신과 함께 콜라겐 합성에 관여하므로(Zhang et al., 2007) 향후 피부미용 관련 소재나 뷰티푸드 소재로 활용될 수 있을 것이다.

\section{5. 쌍별귀뚜라미 분말과 분말 단백질 추출물의 항산화 효과}

1) Total polyphenol 함량

쌍별귀뚜라미 분말과 분말 단백질 추출물의 total polyphenol 함 량을 측정한 결과는 Table 5 에 제시된 바와 같다. Total polyphenol

Table 4. The non-essential amino acids (NEAA) content of cricket (Gryllus bimaculatus) powder and protein extract

\begin{tabular}{lrc}
\hline \multirow{2}{*}{ Amino acids } & Samples $(\mathrm{mg} / \mathrm{kg})$ & CPPE \\
\cline { 2 - 3 } Aspartic acid & CPE & 1571.11 \\
Glutamic acid & 19451.30 & 3266.08 \\
Asparagine & 36085.54 & NA \\
Serine & 338.44 & 730.02 \\
Glutamine & 18447.13 & NA \\
Glycine & 639.49 & 2617.74 \\
Alanine & 21944.58 & 1965.78 \\
Taurine & 31947.01 & 83.44 \\
GABA & 3309.13 & NA \\
Tyrosine & 104.35 & 1351.96 \\
Proline & 17053.70 & NA \\
\hline
\end{tabular}

CPE, cricket (Gryllus bimaculatus) powder extract; CPPE, cricket (Gryllus bimaculatus) protein powder extract.

Table 5. Antioxidant activity of cricket (Gryllus bimaculatus) powder and protein extract

\begin{tabular}{lcc}
\hline & & Samples \\
\cline { 2 - 3 } & CPE & CPPE \\
DPPH (\%) & 68.25 & 80.37 \\
Total polyphenol (mg GAE/g) & 6.61 & 12.18 \\
\hline
\end{tabular}

CPE, cricket (Gryllus bimaculatus) powder extract; CPPE, cricket (Gryllus bimaculatus) protein powder extract; GAE, gallic acid equivalents. 
함량은 쌍별귀뚜라미 분말 $6.61 \mathrm{mg} \mathrm{GAE} / \mathrm{g}$, 분말 단백질 추출물 $12.18 \mathrm{mg} \mathrm{GAE} / \mathrm{g}$ 로 나타나 쌍별귀뚜라미 분말 단백질 추출물의 총 폴리페놀 함량이 높게 나타났다. 이는 식물성 식품인 더덕 14.44 $\mathrm{mg} \mathrm{TAE} / \mathrm{g}$ 과 비슷한 수준이고 당근 $8.36 \mathrm{mg} \mathrm{TAE} / \mathrm{g}$ 보다는 많아 식물성 식품만큼 항산화성도 우수한 것으로 나타났다(Jung et al., 2019). 페놀성 화합물은 식물계에 있는 물질로 항산화활성의 간접 적 지표로 활용될 수 있는 것으로 생체 내에서 발생하는 활성산소종 의 발생을 억제하여(Lim et al., 2017) 체내에서 지질과 단백질이 산 화되는 것을 막아 세포 손상을 억제하고 비정상적인 세포의 성장 분 화를 억제하므로 암 발생 개시단계를 차단하여 암 발암을 예방할 수 있는 인자로 알려져 있다(Wattenberg, 1985). 그러므로 본 연구결 과에서 총 폴리페놀 함량이 높게 나타난 것은 항산화력이 우수하다 는 것으로 노화와 각종 암을 예방하는 소재로서의 가능성도 제시하 는 결과로 사료된다.

\section{2) DPPH radical 소거능}

$\mathrm{DPPH}$ radical 소거능은 안정적인 자유라디칼로 함황 아미노산인 시스테인(cysteine), 글루타티온(glutathion), 방향족아민(aromatic amine), 아스코르브산(ascorbic acid)등에 의해 환원되어 보라색의 $\mathrm{DPPH}$ 가 무색의 diphenyl-picrylhydrazine으로 탈색되면서 흡광 도가 변하는 원리를 이용한 항산화능 측정에 유용한 방법으로(Cho et al., 2011; Ophir et al., 1983; Re et al., 1999) Table 5에 제 시된 바와 같다. 쌍별귀뚜라미 분말과 분말 단백질 추출물의 $\mathrm{DPPH}$ radical 소거능은 $68.25 \%, 80.37 \%$ 로 매우 높게 나타났으며 단백질 분말 추출물의 소거능이 더 높게 나타났다. 본 실험에서 나타난 결 과는 갈색거저리 에탄올 추출물의 DPPH radical 소거능이 $16.2 \%$ 라 고 한 결과(Yu et al., 2016)보다 매우 높게 나타나 아미노산 함량도 우수할 뿐 아니라 동물성 항산화식품으로서의 가치도 매우 클 것으 로 기대된다. 항산화물질은 체내의 세포 산화 및 활성 라디칼을 소 거하여 노화를 억제하며(Chong et al., 2017), 고혈압 완화, 면역기 능 증진 등 여러 가지 생리기능을 증진시키는 것으로 알려져 있어 본 연구결과는 항산화 활성이 우수한 식소재나 식품 더 나아가 이너 뷰티 푸드로서의 활용가능성을 시사하는 것으로 사료된다.

\section{Conclusion}

이상의 결과 쌍별귀뚜라미 분말과 분말 단백질 추출물은 단백질 함량은 많고 지방은 적게 함유되어 있었으며 필수 아미노산 조성이 우수하고 특히 근육관련 아미노산인 발린, 루이신, 이소루이신도 많 이 함유되어 있었다. 또한 폴리페놀 함량이 높고 $\mathrm{DPPH}$ 라디칼 소거 능이 우수하였다. 그러므로 쌍별귀뚜라미는 향후 동물성 단백질을 대체할 수 있는 양질의 단백질 식품으로서 뿐 아니라 항산화 증진 식소재나 식품, 근감소 예방 및 뷰티 푸드로서의 활용 가능성이 있
을 것으로 사료되므로 이에 대한 연구가 더 진행되기를 기대하는 바 이다.

\section{Acknowledgements}

이 논문은 2019 년 한국연구재단의 학문균형발전지원(창의도전 연구)을 받아 수행된 연구임(NRF-2019R1I1A1A01041076).

\section{Author's contribution}

JSH designed, performed study, interpreted data, and wrote the manuscript. YK supported experiment equipment and advice. SHK performed experiment of research project. All tables are created by the author and SHK.

\section{Author details}

Si-Hyun Kim (Graduate student), Department of Human Ecology, Korea University, 145 Anam-ro, Seongbuk-gu, Seoul 02841, Korea; Yookyung Kim (Professor), Department of Home Economics Education, College of Education, Korea University, 145 Anam-ro, Seongbuk-gu, Seoul 02841, Korea; Jung-Soon Han (Research Professor), Research Institute of Human Ecology, Korea University, 145 Anamro, Seongbuk-gu, Seoul 02841, Korea.

\section{References}

Alston JM, Beddow JM, Pardey PG. Agriculture. agricultural research, productivity, and food prices in the long run. Science, 325: 1209-1210, 2009.

Ahn MY, Hwang JS, Yoon HJ, Park K, Kim S, Kim EM. Fasting conditions and dietary phenomena of edible cricket (Gryllus bimaculatus). Journal Sericultural and Entomological Science, 53: 78-81, 2015.

Arsenault JE, Brown KH. Effects of protein or amino-acid supplementation on the physical growth of young children in low-income countries. Nutrition Reviews, 75: 699-717, 2017.

Baek M, Hwang JS, Kim MA, Kim SH, Goo TW, Yun EY. Comparative analysis of nutritional components of edible insects registered as novel foods. Journal of Life Science, 27: 334-338, 2017.

Cho HT, Sim KS, Kim Y, Chang MH, Kim T, Lee SH, Lee DH, Kim JH. Anti-diabetic activity of edible insect Gryllus bimaculatus extracts in insulin-deficient diabetic mice. 
Journal of the Korean Society of Food Science and Nutrition, 48: 1165-1171, 2019.

Cho KJ, Cha JY, Yim JH, Kim JH. Effects of aging temperature and time on the conversion of garlic (Allium sativum L.) components. Journal of the Korean Society of Food Science and Nutrition, 40: 84-88, 2011.

Chong HS, Kim SY, Cho SR, Park HI, Baek JE, Kuk JS, Suh $\mathrm{HJ}$. Characteristics of quality and antioxidant activation of the cookies adding with mealworm (Tenebrio molitor) and black bean powder. Journal of Food Hygiene and Safety, 32: 521-530, 2017.

Chung MY, Kwon EY, Hwang JS, Goo TW, Yun EY. Pretreatment conditions on the powder of Tenebrio molitor for using as a novel food ingredient. Journal of Sericulture Entomological Science, 51: 9-14, 2013.

Han JS, Kim Y. Effects of a weight management program on body composition, and calcium, zinc, and iron intake in middle-aged women with obesity. Asian Journal of Beauty and Cosmetology, 17: 15-24, 2019.

Hegsted DM, Ausman LM, Johnson JA, Dallal GE. Dietary fat and serum lipids: an evaluation of the experimental data. The American Journal of Clinical Nutrition, 57: 875-883, 1993.

Hwang SY, Choi SK. Quality characteristics of muffins containing mealworm (Tenebrio molitor). Culinary Science \& Hospitality Research, 21: 104-115, 2015.

Jung JH, Lim BG, Bae SJ. Study on consumers' perception of edible insect foods. Journal of the Korean Society of Food Culture, 33: 558-566, 2018.

Jung YH, Han JS, Kim AJ. Quality evaluation and antioxidant activity of inner beauty tea prepared from roasted lotus root and burdock. Asian Journal of Beauty and Cosmetology, 17: 235-245, 2019.

Kang MS, Kim MJ, Han JS, Kim AJ. Fatty acid composition and anti-inflammatory effects of the freeze dried Tenebrio molitor Larva. The Korean Journal of Food and Nutrition, 30: 251-256, 2017.

Kim HM, Kim JN, Kim JS, Jeong MY, Yun EY, Hwang JS, Kim AJ. Quality characteristics of patty prepared with mealworm powder. The Korean Journal of Food and Nutrition, 28: 813-820, 2015.

Kim SH, Kim KB, Noh JS, Yun EY, Choi SK. Quality characteristics of pasta with addition of mealworm
(Tenebrio molitor). FoodService Industry Journal, 10: 5564, 2014.

Lee SM, Han JS, Kim AJ. Quality evaluation of Perilla seed Gangjung added with mealworm powder. Asian Journal of Beauty and Cosmetology, 17: 187-197, 2019.

Lee JT, Kang KO. A study on popularization and vitalization of edible insects by changing consumer perceptions and developing recipes: focus on college students in Seoul. FoodService Industry Journal, 15: 49-68, 2019.

Lim HJ, Kim MS, Kim DS, Kim HS, Pae SB, Kim JK, Shin EC. Comparison of lipid constituents and oxidative properties between normal and high-oleic peanuts grown in Korea. Korean Journal of Food Science and Technology, 49: 235-241, 2017.

Min KT, Kang MS, Kim MJ, Lee SH, Han JS, Kim AJ. Manufacture and quality evaluation of cookies prepared with mealworm (Tenebrio molitor) powder. The Korean Journal of Food and Nutrition, 29: 12-18, 2016.

$\mathrm{Na}$ EJ, Jang HH, Kim GR. Review of recent studies and research analysis for anti-oxidant and anti-aging materials. Asian Journal of Beauty and Cosmetology, 14: 481-491, 2016.

No JK. A study of the sarcopenic obesity in aging. Asian Journal of Beauty and Cosmetology, 8: 139-148, 2010.

Ophir O, Peer G, Gilad J, Blum M, Aviram A. Low blood pressure in vegetarians: the possible role of potassium. The American Journal of Clinical Nutrition, 37: 755-762, 1983.

Re R, Pellegrini N, Proteggente A, Pannala A, Yang M, RiceEvans C. Antioxidant activity applying an improved ABTS radical cation decolorization assay. Free Radical Biology and Medicine, 26: 1231-1237, 1999.

Singer P, Jaeger W, Berger I, Barleben H, Wirth M, RichterHeinrich E, Voigt S, Gödicke W. Effects of dietary oleic, linoleic and alpha-linolenic acids on blood pressure, serum lipids, lipoproteins and the formation of eicosanoid precursors in patients with mild essential hypertension. Journal of Human Hypertension, 4: 227233, 1990.

Wattenberg LW. Chemoprevention of cancer. Cancer Research, 45: 1-8, 1985.

Yu JM, Jang JY, Kim HJ, Cho YH, Kim DI, Kwon OJ, Cho YJ, An BJ. Antioxidant capacity and Raw 264.7 macrophage 
anti-inflammatory effect of the Tenebrio molitor. Korean Journal of Food Preservation, 23: 890-898, 2016.

Zhang Y, Guo K, LeBlanc RE, Loh D, Schwartz GJ, Yu $\mathrm{YH}$. Increasing dietary leucine intake reduces diet- induced obesity and improves glucose and cholesterol metabolism in mice via multimechanisms. Diabetes, 56: 1647-1654, 2007. 


\section{국문초록}

\section{쌍별귀뚜라미 분말과 분말 단백질 추출물의 영양성분과 항산화 활성}

김시현 ${ }^{1}$, 김유경 ${ }^{2}$ 한정순 ${ }^{*}$

${ }^{1}$ 고려대학교 생활과학과, 서울, 한국

${ }^{2}$ 고려대학교 사범대학 가정교육과, 서울, 한국

${ }^{3}$ 고려대학교 생활과학연구소, 서울, 한국

목적: 본 연구는 쌍별귀뚜라미 분말과 분말 단백질추출물의 아미노산 조성과 항산화 활성을 탐색하고자 수행되었다. 방법: 쌍별 귀뚜라미 분말의 일반성분과 분말 단백질추출물의 무기질 성분은 Association of Official Analytical Chemists (AOAC) 방법, 아미 노산은 아미노산 분석기로 측정하였다. 항산화 활성은 총 폴리페놀, 1,1-diphenyl-2-picrylhydrazyl (DPPH) 소거능을 측정하였 다. 결과: 쌍별귀뚜라미 분말의 칼슘과 칼륨 함량이 쌍별귀뚜라미 분말 단백질 추출물보다 많이 함유되어 있었다. 쌍별귀뚜라미 분 말 추출물과 분말단백질 추출물에는 필수 아미노산과 비필수 아미노산이 많이 함유되어 있었다. 특히 쌍별귀뚜라미 분말 추출물 에는 분지아미노산인 발린 $17186.31 \mathrm{mg} / \mathrm{kg}$, 이소루이신 $12790.01 \mathrm{mg} / \mathrm{kg}$, 루이신 $25382.52 \mathrm{mg} / \mathrm{kg}$, 분말 단백질 추출물에는 발 린 $1147.28 \mathrm{mg} / \mathrm{kg}$, 이소루이신 $1281.90 \mathrm{mg} / \mathrm{kg}$, 루이신 $2753.34 \mathrm{mg} / \mathrm{kg}$ 으로 분말 추출물의 분지아미노산 함량이 높았다. Total polyphenol 함량은 쌍별귀뚜라미 단백질 추출물(12.18 mg GAE/g), 쌍별귀뚜라미 분말 추출물(6.61 mg GAE/g), DPPH radical 소 거능은 쌍별귀뚜라미 단백질 추출물(80.37\%), 쌍별귀뚜라미 분말 추출물(68.25\%)로 단백질 추출물에서 높게 나타났다. 결론: 쌍별 귀뚜라미는 단백질 함량은 높고 지방함량은 낮았으며 특히 아미노산조성이 우수하고 분지아미노산도 함유되어 있었으며 항산화 활 성이 높아 근감소 억제, 항산화 및 뷰티 푸드 관련 식품소재나 식품으로서의 활용가능을 제시하는 것으로 사료된다.

핵심어: 쌍별귀뚜라미 분말, 쌍별귀뚜라미 분말 추출물, 아미노산, 무기질, 항산화활성

이 논문은 2019년 한국연구재단의 학문균형발전지원(창의도전연구)을 받아 수행된 연구임(NRF- 2019R1I1A1A01041076).

\section{참고문헌}

강미숙, 김민주, 한정순, 김애정. 동결건조 갈색거저리 유충의 지방산 조성과 항염증 효과. 한국식품영양학회지, 30 : 251-256, 2017.

김수희, 김기쁨, 노재승, 윤은영, 최수근. 갈색거저리를 첨가한 파스타의 품질특성. 한국외식산업학회지, 10: 55-64, 2014.

김형미, 김정남, 김진수, 정미영, 윤은영, 황재삼, 김애정. 갈색거저리 유충 분말을 이용한 패티 제조 및 품질특성. 한국식 품영양학회지, 28: 813-820, 2015.

나은주, 장현희, 김규리. 자연유래 항산화 원료와 제품개발을 위한 항산화 및 항노화 연구의 최신동향. 아시안뷰티화장품 학술지, 14: 481-491, 2016.

노재경. 노화과정에서 저근육형 비만에 대한 이론적 연구. 아시안뷰티화장품학술지, 8: 139-148, 2010.

민경태, 강미숙, 김민주, 이선희, 한정순, 김애정. 갈색거저리 유충 분말을 이용한 쿠키 제조 및 품질평가. 한국식품영양학 회지, 29: 12-18, 2016.

백민희, 황재삼, 김미애, 김수희, 구태원, 윤은영. 새로운 식품원료로 등록된 식용곤충의 영양성분 비교분석. 생명과학회 지, 27: 334-338, 2017.

안미영, 황재삼, 윤형주, 박꽃하얀, 김성현, 김은미. 쌍별귀뚜라미 식품 용도 개발에 따른 절식조건. 한국잠사곤충학회지, 53: 78-81, 2015. 
유재묘, 장재윤, 김현정, 조용훈, 김동인, 권오준, 조영제, 안봉전. 갈색거저리(Tenebrio Molitor)의 항산화능과 Raw 264.7 대식세포의 항염증 효과. 한국식품저장유통학회지, 23: 890-898, 2016.

이선미, 한정순, 김애정. 밀웜 분말 첨가 들깨강정의 품질 평가. 아시안뷰티화장품학술지, 17: 187-197, 2019.

이진태, 강근옥. 식용곤충에 대한 소비자들의 인식과 메뉴개발을 통한 대중화 활성화 방안 연구: 서울지역 대학생을 중심 으로. 한국외식산업학회지, 15: 49-68, 2019.

임호정, 김미소, 김다솜, 김회성, 배석복. 국내산 땅콩의 일반 품종과 고올레산 품종에 대한 지용성 영양성분과 산화안정성 비교. 한국식품과학회지, 49: 235-241, 2017.

정미연, 권은영, 황재삼, 구태원, 윤은영. 갈색거저리의 식품 원료화를 위한 분말제조 조건 확립. 한국잠사곤충학회지, $51:$ 9-14, 2013.

정연희, 한정순, 김애정. 로스팅한 연근과 우엉을 이용한 이너 뷰티 차의 항산화 활성과 품질평가. 아시안뷰티화장품학술 지, 17: 235-245, 2019.

정주희, 임배균, 배세정. 식용곤충식품에 대한 소비자 인식 연구. 한국식생활문화학회지, 33: 558-566, 2018.

정희선, 김수연, 조성륜, 박현일, 백지은, 국지수, 서희재. 식용 밀웜(Tenebrio molitor)분말과 검은콩 분말을 첨가한 쿠키 의 품질특성 및 항산화 활성. 한국식품위생안전성학회지, 32: 521-530, 2017.

조강진, 차지영, 임주혁, 김재현. 온도 및 숙성기간이 마늘의 화학적 성분변화에 미치는 영향. 한국식품영양과학회지, 40 : 84-88, 2011.

조형택, 심규상, 김에나, 장문한, 김태완, 이승환, 이동희, 김준호. 인슐린 결핍 당뇨 마우스에서 식용곤충 쌍별귀뚜라미 추출물의 항당뇨 활성. 한국식품영양과학회지, 48: 1165-1171, 2019.

한정순, 김유경. 체중관리 프로그램이 중년비만여성의 체성분과 칼슘, 아연, 철 섭취에 미치는 영향. 아시안뷰티화장품학 술지, 17: 15-24, 2019.

황수영, 최수근. 밀웜(갈색거저리) 분말 첨가 머핀의 품질 특성. Culinary Science \& Hospitality Research, 21: 104115, 2015. 


\section{中文摘要}

\section{蟋蟀粉和其蛋白质提取物的营养成分以及抗氧化活性}

金侍賢 ${ }^{1}$, 金有京 $^{2}$, 韓正順 $^{3 *}$

高丽大学生活科学科, 首尔, 韩国

2高丽大学师范大学家政教育科, 首尔, 韩国

高丽大学生活科学研究所, 首尔, 韩国

目的：研究蟋蟀粉和粉末蛋白质提取物的氨基酸组成和抗氧化活性。方法：根据官方分析化学家协会 (Association of Official Analytical Chemists, AOAC) 指南, 通过化学分析测定水分、粗脂肪、蛋白质和 矿物质含量。用氨基酸自动分析仪分析氨基酸组成。CPE[蟋蟀（G.bimaculatus）粉末提取物]和CPPE[蟋 蟀 (G.bimaculatus) 粉末蛋白提取物]的抗氧化活性通过评估总多酚含量和1,1-diphenyl-2-picrylhydrazyl (DPPH)自由基清除活性来计算。结果: CPE的钻和钾含量均高于CPPE。CPE的必需氨基酸含量高于CPPE。CPE 支链氨基酸含量[即芣氨酸（CPE，17186.31 mg/kg；CPPE，1147.28 mg/kg）、亮氨酸（CPE， 25382.52 $\mathrm{mg} / \mathrm{kg}$; CPPE, $2753.34 \mathrm{mg} / \mathrm{kg}$ ) 和异亮氨酸 (CPE, $12790.01 \mathrm{mg} / \mathrm{kg}$; CPPE, $1281.90 \mathrm{mg} / \mathrm{kg}$ ) ]明显高于 CPPE。CPPE的总多酚含量（12.18 mg GAE/g）高于CPE（6.61 mg GAE/g）。CPPE对DPPH自由基的清除率 (80.37\%) 也高于CPE (68.25\%) 。结论: 蟋蟀是一种适宜的蛋白质和天然抗氧化剂。今后, 应进一步研究蟋 蟀对健康的益处。

关键词: 蟋蟀粉, 蛋白质提取物, 氨基酸, 矿物质, 抗氧化活性 